\title{
DOPRINOS RASPRAVI O NAČELU JEDNAKOSTI PROCESNIH SREDSTAVA*
}

Dr. sc. Dejan Bodul, docent

Dr. sc. Sanja Grbić, docentica

Pravni fakultet Sveučilišta u Rijeci
UDK 347.9:341.231.14(4)

Ur.: 20. siječnja 2017.

Pr.: 6. veljače 2017.

Prethodno priopćenje

\section{Sažetak}

Načelo jednakosti procesnih sredstava zahtijeva postojanje razumne mogućnosti obaju stranaka da izlože činjenice i podupru ih svojim dokazima, tako da niti jednu stranku ne stavljaju u bitno lošiji položaj u odnosu na suprotnu stranku (predmet LB INTERFINANZ A.G. protiv Hrvatske, presuda, 27.03.2008., zahtjev br. 29549/04.). U smislu procesne ravnoteže među strankama navedeno čini jedan od bitnih konstitutivnih elemenata prava na pošteno suđenje. Ipak, donošenjem (novog) Stečajnog zakona (NN, 71/15. dalje SZ) pitanje jednakosti procesnih sredstava ponovno se aktualizira. Naime, SZ je zadržao rješenje po kojem je vjerovnik u mogućnosti pokretati stečajni postupak ako učini vjerojatnim postojanje svoje tražbine i postojanje stečajnog razloga, s tim da je zadržano $i$ osporeno rješenje po kojem vjerojatnost postojanja tražbine vjerovnik može dokazivati temeljem nepravomoćne sudske ili upravne odluke. Kako postoje različita rješenja po pitanju navedenih pretpostavki, autori će se ograničiti na opće konstatacije zasnovane na poredbenim iskustvima, bez detaljnog razmatranja brojnih i raznolikih specifičnih usporednih rješenja. U radu se razmatraju $i$ praktičke, ali $i$ teorijske implikacije pozitivno-pravnog rješenja posebno analizirajući praksu Europskog suda za ljudska prava u postupcima prema čl. 6. (Pravo na pošteno suđenje) Europske konvencije za zaštitu ljudskih prava i temeljnih sloboda, jer polaze od pretpostavke da saznanja o tomu mogu biti ključna za razumijevanje problematike rada. Pokušava se odgovoriti i na pitanje zahtijevaju li sveukupno loši indikatori stečajnog postupka, koji su rezultat strukturalnih problema, "strože" postupovne mjere radi razrješenja takve situacije. Predmet analize bit će i nomotehnička dimenzija ovog pitanja, budući da je za isto rješsenje u starom Stečajnom zakonu (NN, 44/96., 29/99., 129/00., 123/03., 82/06., 116/10., 25/12. i 45/13.) pred Ustavnim sudom RH pokrenut postupak za ocjenu suglasnosti s Ustavom te je do donošenja konačne odluke privremeno obustavljeno izvršenje svih pojedinačnih akata i radnji koje se poduzimaju na temelju osporene zakonske odredbe.

Ključne riječi: stečaj, vjerovnik, pokretanje postupka, vjerojatnost tražbine, dokazivanje.

* Ovaj rad je nastao uz potporu Hrvatske zaklade za znanost u okviru projekta 6558 Business and Personal Insolvency - the Ways to Overcome Excessive Indebtednes. 


\section{O NAČELU JEDNAKOSTI PROCESNIH SREDSTAVA U KONTEKSTU PRAVA NA POŠTENO SUĐENJE}

Članak 6., stavak 1. Europske konvencije za zaštitu ljudskih prava i temeljnih sloboda ${ }^{1}$ određuje da radi utvrđivanja građanskih prava i obveza svatko ima pravo da njegov slučaj ispita zakonom ustanovljeni, nezavisni i nepristrani sud u javnom i pravičnom postupku te u razumnom roku. On govori o pravu na pošteno suđenje te je jedna od najznačajnijih odredbi koja je detaljno razrađena u praksi Europskog suda za ljudska prava (dalje: ESLJP). Stoga, je u odnosu za ovaj članak podneseno najviše zahtjeva i doneseno najviše presuda kojima je ESLJP proširio tekst čl. 6. EKLJP-a tumačeći postojeća i stvarajući nova prava i načela. Načelo jednakosti oružja i kontradiktornost postupka nisu izričito navedena u tekstu EKLJP-a, međutim ona su jedna od važnijih načela stvorenih praksom ESLJP-a i čine neizostavni dio prava na pošteno suđenje. Prema čl. 6. načelo jednakosti oružja (ravnopravnosti stranaka) omogućava pravičnu ravnotežu među strankama u (kaznenim i) građanskim postupcima. ${ }^{2}$ Ono podrazumijeva da svaka stranka u postupku treba imati jednaku mogućnost izložiti svoj predmet, kao i iznositi dokaze koje ona smatra potrebnim, a sve to u okolnostima koje jednu stranku ne stavljaju u nepovoljniji položaj u odnosu na drugu u konkretnom postupku. Dakle, tako postavljeno načelo jednakosti oružja predstavlja u judikaturi ESLJP-a osnovni element prava na pošteni postupak. ${ }^{3}$ Međutim, ESLJP nije dao njegovu točnu definiciju jer je riječ o "kvalifikaciji ili pravnom predočenju" koje se neprestano razvija njegovom sudskom praksom. Njegov značaj za ostvarivanje prava na pošteno suđenje, istaknut je najprije u mišljenju Komisije 1959. u građanskom postupku ${ }^{4}$ u kojemu su pozivanjem na načelo jednakosti oružja, proširena prava na pošteno suđenje. ${ }^{5}$

1 EKLJP, NN - MU, 18/97., 6/99., 14/02., 13/03., 9/05., 1/06. i 2/10.

1. Radi utvrđivanja svojih prava i obveza građanske naravi ili u slučaju podizanja optužnice za kazneno djelo protiv njega svatko ima pravo da zakonom ustanovljeni nezavisni i nepristrani sud pravično, javno i u razumnom roku ispita njegov slučaj. Presuda se mora izreći javno, ali se sredstva priopćavanja i javnost mogu isključiti iz cijele rasprave ili njezinog dijela zbog razloga koji su nužni u demokratskom društvu radi interesa morala, javnog reda ili državne sigurnosti, kad interesi maloljetnika ili privatnog života stranaka to traže, ili u opsegu koji je po mišljenju suda bezuvjetno potreban u posebnim okolnostima gdje bi javnost mogla biti štetna za interes pravde.

2 Feldbrugge protiv Nizozemske, presuda, 27. srpnja 1987., br. 8562/79.

3 Vidi Reid, K., A Practitioner's guide to European Convention on Human Rights, London, Sweet \& Maxwell, Thomson Reuters, 2012., str. 143.

4 Szwabowic protiv Švedske, odluka, 30. lipnja 1959., br. 434/58.

5 Prvi predmetiu kojimaje ESLJP istaknuo važnost načela jednakosti oružja bili su Neumeister protiv Austrije (presuda, 27. lipnja 1968., br. 1936/63.), Delcourt protiv Belgije (presuda, 17. siječnja 1970., br. 2689/65.) i Bonisch protiv Austrije (presuda, 2. lipnja 1986., br. 8658/79.). Podrobnije, Stavros, S., The guarantees for accused persons under article 6 of the European Convention on Human Rights, An Analysis of the Application of the Convention and a comparison with Other Instruments, Martinus Nijhoff Publishers, Dordrecht, Boston, London, 1993., str. 52. Iako su se navedeni predmeti odnosili na kaznene postupke načelo jednakosti oružja postalo je jednako priznato i važno u građanskim postupcima. Detaljnije, Grbić, S., Pošteno suđenje u građanskim postupcima u Hrvatskoj u svjetlu čl. 6., st. 1. Europske konvencije o ljudskim 


\section{DEFINIRANJE PROBLEMA}

Stečajni zakoni većine zemalja predviđaju da su i vjerovnici aktivno legitimirane osobe za pokretanje stečajnog postupka. Praksa provođenja stečajnih postupaka u Republici Hrvatskoj, međutim dokazuje da krajnji cilj vjerovnika kao predlagatelja nije otvaranje stečajnog postupka kao generalne ovrhe nad imovinom dužnika, već je cilj ovrhom namiriti se od dužnika prije samog otvaranja stečaja tako da mu dužnik isplati potraživanje iz prijedloga za otvaranje stečajnog postupka, a nakon čega će sud obustaviti postupak utvrđivanja uvjeta za otvaranje stečajnog postupka. Prvotno, problem se javio kada je čl. 13., st. 1. Zakona o izmjenama i dopunama Stečajnog zakona (NN, 133/12. od 03.12.2012.) redefinirao pretpostavke za pokretanje

pravima, Pravni fakultet, Rijeka, 2014., str. 92. et seq. Budući da je pravična ravnoteža među strankama više "narušena" prirodom kaznenog postupka, veći broj predmeta iz sudske prakse ESLJP-a odnosio se na kaznene postupke. To je zbog toga što se u građanskom postupku vodi spor između dviju jednakih stranaka pred nezavisnim sudom, dok u kaznenom postupku veliku ulogu ima postupanje tijela kaznenog postupka koje je nadležno za poduzimanje represivnih radnji i mjera protiv gonjene osobe, tj. optuženika prema čl. 6. Podrobnije, Ivičević Karas, E., Načelo jednakosti oružja kao konstitutivni element prava na pravični kazneni postupak iz članka 6. Europske konvencije za zaštitu ljudskih prava i temeljnih sloboda, Zbornik Pravnog fakulteta Sveučilišta u Zagrebu, vol. 57, 2007., br. 4 -5, str. 761 - 778. Međutim, ESLJP je zbog velike važnosti koju u poštenom postupku ima načelo jednakosti oružja, kriterije stvorene sudskom praksom u kaznenim predmetima proširio i na građanske predmete (Guigue i SGENCFDT protiv Francuske, odluka, 6. siječnja 2004., br. 59821/00.). Tako se u poštenom postupku nastoje uskladiti položaji stranaka ostvarenjem različitih postupovnih načela, a jednakost oružja jedno je od njih (Gomien, D., Europska konvencija o ljudskim pravima, Rijeka, Naklada, Pravni fakultet Sveučilišta u Rijeci, 2007., str. 99.). U predmetu Dombo Beheer protiv Nizozemske (presuda, 27. listopada 1993., br. 14448/88.) ESLJP je istaknuo: "Objema strankama u postupku mora biti dana razumna mogućnost za izlaganje svojeg predmeta uključujući i iznošenje dokaza pod uvjetima koji ih ne stavljaju u znatno podređeni položaj u odnosu na protivnika." U Stran Greek Refineries i Stratis Andreadis protiv Grčke (presuda, 9. prosinca 1994., br. 13427/87.) ESLJP je također utvrdio povredu načela jednakosti oružja jer je u Grčkoj bio usvojen zakon kojemu je cilj bio osigurati neuspjeh podnositelja u postupku pred nacionalnim sudom. U De Haes $i$ Gijsels protiv Belgije (presuda, 24. veljače 1997., br. 19983/92.) ESLJP je ustanovio povredu načela jednakosti oružja jer je jedna od stranaka u postupku bila u povoljnijem položaju zbog posla kojeg je obavljala te je zbog toga nacionalni sud onemogućio protivnoj strani izjašnjavanje o iznesenim dokazima kao i podnošenje dokaza koji su za nju bili relevantni u konkretnom predmetu. Vidi Guide on Article 6 of the Convention - Right to a fair trial (civil limb), Council of Europe, 2013., dostupno na mrežnim stranicama: http://www.echr.coe.int/ Documents/Guide_Art_6_ENG.pdf (20.11.2016.). ESLJP je utvrdio i da načelo jednakosti stranaka pred sudom podrazumijeva da stranke moraju imati jednak pristup spisima i drugim dokumentima, barem u onoj mjeri u kojoj je to bitno radi donošenja odluke suda koji odlučuje o tom predmetu (McMichael protiv Ujedinjenog Kraljevstva, presuda, 24. veljače 1995., br. 16424/90.). U presudi F. R. protiv Švicarske presuda 28. lipnja 2001., br. $37292 / 97$ i Ferreira Alves protiv Portugala, presuda, 21. lipnja 2007., br. 25053/05 iznio je: "(..) koncept poštenog suđenja podrazumijeva također, u načelu i pravo stranaka da u postupku budu upoznate sa dokazima, ta da imaju mogućnost iznijeti svoje argumente o izvedenim dokazima ili izjavama koje se nalaze u spisu predmeta. (...). Ono što je ovdje od posebnog značaja je povjerenje stranaka u sporu u funkcioniranje pravde, koje se zasniva, inter alia, na spoznaji da su imali priliku iskazati svoje mišljenje o svakom dokumentu koji se nalazi u spisu predmeta." Vidi Dutertre, G., Izvodi iz sudske prakse - Evropski sud za ljudska prava, IMTEC, Sarajevo, 2002., str. 178. et seq. 
stečajnog postupka odnosno prijedlog za otvaranje stečajnog postupka koji podnosi vjerovnik. Naime, zakonodavac je uz postojeću odredbu čl. 39., st. 2. starog Stečajnog zakona vjerovnik je ovlašten podnijeti prijedlog za otvaranje stečajnog postupka ako učini vjerojatnim postojanje svoje tražbine i kojega od stečajnih razloga dodao rečenicu koja glasi: Smatrat će se da je vjerovnik učinio vjerojatnim postojanje svoje tražbine ako njezino postojanje temelji na ovršnoj ispravi ili nepravomoćnoj sudskoj ili upravnoj odluci. Dakle, dopunom SZ-a uvela se presumpcija postojanja vjerojatnosti vjerovnikove tražbine u slučajevima u kojima vjerovnik raspolaže određenim ispravama radi otklanjanja uočenog različitog tumačenja, odnosno opsega i značenja tog pravnog standarda od sudova. Članak 39., stavak 2. starog Stečajnog zakona nakon navedene izmjene glasi: Vjerovnik je ovlašten podnijeti prijedlog za otvaranje stečajnog postupka ako učini vjerojatnim postojanje svoje tražbine i kojega od stečajnih razloga. Smatrat će se da je vjerovnik učinio vjerojatnim postojanje svoje tražbine ako njezino postojanje temelji na ovršnoj ispravi ili nepravomoćnoj sudskoj ili upravnoj odluci. ${ }^{6}$

6 Zanimljivo je i pogledati pravnu genezu ovog rješenja do donošenja Zakona o izmjenama i dopunama Stečajnog zakona (NN, 133/12. od 03.12.2012.). Temeljem Zakona o prisilnoj nagodbi, stečaju i likvidaciji (NN, 54/94.) vjerovnik je, kao predlagatelj otvaranja stečajnog postupka nad dužnikom, nadležnom trgovačkom sudu morao dokazati: 1.) trajniju nesposobnost za plaćanje dužnika (tzv. insolventnost) (čl. 2.) te 2.) predočiti isprave o postojanju svoga novčanog potraživanja koje nije mogao ni prisilnim izvršenjem naplatiti od dužnika (čl. 72.). To znači da je vjerovnicima praktički bilo onemogućeno uspjeti u pokušaju otvaranja stečajnog postupka nad dužnikom. S druge strane, Stečajni zakon koji je stupio na snagu 01. siječnja 1997. (NN, 44/96.), uvodi puno blaže kriterije koje vjerovnik mora ispuniti kao predlagatelj otvaranja stečajnog postupka nad dužnikom. Vjerovnik je, po novom ovlašten podnijeti prijedlog ako učini vjerojatnim: 1.) postojanje svoje tražbine i 2.) kojega od stečajnih razloga (nesposobnost za plaćanje i prezaduženost) (čl. 39., st. 2. SZ). Vjerojatnost postojanja svoje tražbine odnosno aktivnu legitimaciju ne mora dokazati pravomoćnom presudom, a niti je bitno je li tražbina dospjela. Visina tražbine nije važna za ovlaštenje za pokretanje stečajnog postupka, a nije bitno niti to ima li dužnik više vjerovnika ili nema. Vjerojatnost postojanja kojega od stečajnih razloga iz čl. 4. starog Stečajnog zakona dokazivala se različito: 1.) protiv dužnika podnesen je veći broj tužbi, 2.) blokada žiro računa dužnika evidentirana je kod ovlaštene organizacije za platni promet (na temelju Izvješća Zavoda za platni promet u skladu s čl. 70. Zakona o izmjenama i dopunama Stečajnog zakona (NN, 129/00.), 3.) poslovanje dužnika preko druge tvrtke i 4.) zatvaranje poslovnih prostorija dužnika i dr.

U nedostatku zakonskog uređenja, tumačenje ovoga pojma bilo je prepušteno pravnoj teoriji i sudskoj praksi. Stoga su trgovački sudovi i Visoki trgovački sud Republike Hrvatske (dalje: VTS RH) imali puno diskrecijsko pravo tumačiti neregulirani pojam vjerojatnosti. U odluci VTS RH, br. Pž-4746/08 od 30. rujna 2008. ističe se: "Kad je uvjerenje suda o relevantnoj činjenici takvo da isključuje svaku razumnu sumnju u njegovu pravilnost i istinitost, prihvaća se kako je određena teza potpuno dokazana, kako postoji izvjesnost o postojanju (ili nepostojanju) i sadržaju određene činjenice. U tom je slučaju riječ o sudskom uvjerenju ili o tzv. "sudskoj istini". U određenim slučajevima - kao kod odlučivanja o postojanju predlagateljeve legitimacije za pokretanje stečajnog postupka - stečajnim sucima je kod izvođenja zaključaka u tom pravcu dano ovlaštenje reducirati svoja uvjerenja sa stupnja izvjesnosti na stupanj vjerojatnosti. Dakle, vjerojatnost je slabiji stupanj uvjerenja o postojanju određene činjenice od izvjesnosti o njenom postojanju. Ona dopušta već i samo utvrđenje mogućnosti da se uvjerenje poklapa sa stvarnošću. U konkretnom slučaju to znači da stečajni sudac nije mogao ulaziti u ispitivanje osnovanosti predlagateljeve tražbine, niti uopće u procjenu međusobnih odnosa 
U predmetu pred Trgovačkim sudom u Zagrebu br. St-67/13 od 28.02.2013. pokrenut je stečajni postupak odnosno postupak radi utvrđivanja uvjeta za otvaranje stečajnog postupka. Prije ročišta radi izjašnjenja o prijedlogu za otvaranje stečajnog postupka, punomoćnik dužnika je Ustavnom sudu podnio: 1.) prijedlog za pokretanje postupka za ocjenu suglasnosti s Ustavom čl. 13., st. 1. ZID SZ-a te 2.) prijedlog za privremenu obustavu izvršenja rješenja Trgovačkog suda u Zagrebu br. St-67/13 od 28. veljače 2013. do donošenja konačne odluke Ustavnog suda o prijedlogu za ocjenu suglasnosti s Ustavom čl. 13., st. 1. ZID SZ-a. U odnosu na prijedlog za pokretanje postupka za ocjenu suglasnosti, punomoćnik dužnika, u bitnom smatra da osporena odredba, time što propisuje zakonsku presumpciju da je vjerovnik učinio vjerojatnim postojanje svoje tražbine ako njezino postojanje temelji na nepravomoćnoj odluci, nije suglasna s čl. 3., 18., st. 1. i 29., st. 1. Ustava RH.7 Nadalje, na temelju prvostupanjske nepravomoćne odluke ne može se uzeti da postoje nečije građanske obveze pa se sukladno tomu vjerovnika koji raspolaže takvom presudom ne smije priznati kao vjerovnika u stečajnom postupku. U odnosu na prijedlog za privremenu mjeru obustave, punomoćnik dužnika smatra da bi otvaranjem stečajnog postupka za njegovu stranku nastale teške i nepopravljive posljedice, između ostalog otpuštanjem radnika, rasprodajom imovine i dr.

Ustavni sud je donio Rješenje U-I/1457/2013. od 11.04.2013. (NN, 45/13.) koje glasi: "I. Pokreće se postupak za ocjenu suglasnosti s Ustavom članka 13. stavka 1. Zakona o izmjenama i dopunama Stečajnog zakona (NN, 133/12.). II. Na temelju čl. 45. Ustavnog zakona o Ustavnom sudu Republike Hrvatske (NN, 99/99., 29/02. i

predlagatelja i dužnika. Nesporna činjenica da je predlagatelj dužniku ispostavio račun za odvjetničke usluge u sporu u kojem ga je doista zastupao, i za ovaj sud su dovoljne za uvjerenje o vjerojatnosti predlagateljeve tražbine, a time i postojanje njegove legitimacije za pokretanje stečajnog postupka nad dužnikom. Sam dužnik ove činjenice nije doveo u pitanje, a njegove tvrdnje o nepravilnostima u zastupanju, šteti itd., moguće je raspraviti samo u redovnoj parnici, a ne u stečajnom (izvanparničnom) postupku, kako je to pravilno naveo i stečajni sudac u obrazloženju pobijanog rješenja." U odluci VTS RH br. Pž-4331/09-3 od 30. srpnja 2009. ističe se, između ostalog i ovo: “...Pri tome se polazi od utvrđenja o postojanju više argumenata koji govore u prilog uvjerenju o postojanju relevantnih činjenica nego onih koji govore protiv. Međutim, pri tome broj argumenata na jednoj strani sam po sebi ne mora biti odlučan, već je odlučan sadržaj, odnosno snaga tih argumenata".

Iz obrazloženja Odluke Ustavnog suda RH (dalje: Ustavni sud), br. U-III-4963/2008. od 30. ožujka 2011., jasno proizlazi da Ustavni sud prihvaća načelno stajalište VTS RH da snaga ukupnih argumenata koji govore u prilog uvjerenju o postojanju relevantnih činjenica znači onu odlučnu činjenicu koja će činiti razliku između izvjesnosti odnosno vjerojatnosti postojanja tražbine u stečajnom postupku. Nadalje, Ustavni sud smatra da bez aktivne legitimacije i postojanja stečajnog razloga u trenutku donošenja odluke o otvaranju stečajnog postupka nema zakonske osnove za otvaranje stečajnog postupka. Konačno, vrlo je bitno naglasiti i ovo zapažanje Ustavnog suda iz obrazloženja navedene Odluke: "Stečajnim zakonom propisana "vjerojatnost postojanja tražbine" je pravni standard, čiji su opseg i značenje trgovački sudovi tijekom svoje prakse sami stvarali i tumačili. Nije, stoga, na Ustavnom sudu da tumači mjerodavno pravo". Tako i podrobnije, Bodul, D., Vuković, A., Pouzdanost kriterija za pokretanje stečajnog postupka, Pravni portal: IUS-INFO, 2016. Dostupno na mrežnim stranicama http://www. iusinfo.hr/ (25.12.2016.).

7 NN, 56/90., 135/97., 8/98., 113/00., 124/00., 28/01., 41/01., 55/01., 76/10., 85/10., 05/14. 
49/02. - pročišćeni tekst), II. Do donošenja konačne odluke Ustavnog suda Republike Hrvatske o suglasnosti s Ustavom čl. 13., st. 1. Zakona o izmjenama i dopunama Stečajnog zakona iz točke I. ove izreke, privremeno se obustavlja izvršenje svih pojedinačnih akata i radnji koje se poduzimaju na temelju osporene zakonske odredbe. III. Do donošenja konačne odluke Ustavnog suda Republike Hrvatske primjenjuje se čl. 39., st. 2. Stečajnog zakona (NN, 44/96., 29/99., 129/00., 123/03., 82/06., 116/10. i 25/12.). IV. Ovo rješenje objavit će se u "Narodnim novinama".

Možda i najvećoj zanimljivosti ovog uratka, pridonosi činjenica da je ubrzo nakon ove odluke Ustavnog suda implementiran novi Stečajni zakon (NN, 71/15. stupio na snagu 01. rujna 2015.) dalje: SZ, koji je ponovno implementirao osporenu zakonsku odredbu, dakle odredbu istovjetnu onoj koju je kao spornu odredio Ustavni sud RH, čak suspendiranu od primjene. ${ }^{9}$ Dakle, čl. 109., st. 2. novog SZ-a određuje "Vjerovnik je ovlašten podnijeti prijedlog za otvaranje stečajnoga postupka ako učini vjerojatnim postojanje svoje tražbine i stečajnoga razloga. Smatrat će se da je vjerovnik učinio vjerojatnim postojanje svoje tražbine ako njezino postojanje temelji na ovršnoj ispravi ili nepravomoćnoj sudskoj ili upravnoj odluci”. ${ }^{10},{ }^{11}$

8 Zanimljiv je i rad, Smerdel, B., Znanost, struka i politika: ustavne promjene, Informator, 2009., br. 5812 , str. $1-2$.

9 Godine 2016. izvršena je velika reforma insolvencijskog zakonodavstva. Ponajprije zbog novih modela reorganizacije implementiran je SZ. Na počelima financijskog oporavka implementiran je i Zakon o stečaju potrošača $(N N, 100 / 15$.) s pratećim propisima. Radi usklađivanja s odredbama SZ-a i Zakona o radu (NN, 93/14), po hitnom postupku noveliran je i Zakon o osiguranju potraživanja radnika u slučaju stečaja poslodavca (NN, 86/08., 80/13. i 82/15.). Radi redefiniranja ovlaštenja i odgovornosti stečajnog upravitelja u SZ-u bilo je, prema shvaćanju zakonodavca, nužno i nomotehnički urediti pitanje nagrade operativnih tijela stečajnog postupka, stečajnog upravitelja, novom Uredbom o kriterijima i načinu obračuna i plaćanja nagrade stečajnim upraviteljima (NN, 105/15.). Bitno je spomenuti i Uredbu o uvjetima, načinu i postupku raspolaganja tražbinama s naslova poreznog duga u predstečajnom i stečajnom postupku (NN, 122/15.), budući da je ista dio iznimno detaljnog i složenog sustava pravila o državnim potporama. Iako domet novog stečajnog zakonodavstva još uvijek nije moguće procijeniti, autori smatraju kako problemi koji onemogućavaju učinkovitiji stečajni postupak nisu načelno vezani uz tekst SZ-a i pratećih propisa, već se u većem dijelu nalaze u primjeni i/ili izvan samoga stečajnog okvira. Dakle, reforma nije bila višestrana, a to se potvrđuje činjenicom kako zakonodavac nije predvidio učinke i posljedice koje će zakonske izmjene proizvesti te zbog toga nije niti pripremio (pravosudni) sustav da ih spremno dočeka. Podrobnije, Bodul, D., Vuković, A., Institucionalni okvir za primjenu stečajnog zakonodavstva - otvorena pitanja, Informator, 2017., br. 6452, str. 1-4.

10 Problematika je analizirana u radu Bodul, D., Vuković, A., Pouzdanost kriterija ... cit.

11 Spuštajući se na praktičnu i empirijsku razinu stečajnog postupka, vidimo kako je stečaj poseban izvanparnični postupak, in extremis, u kojem je vrijeme jedan od najznačajnijih elemenata. Stoga mogućnost koju ima sud, ako utvrdi da pojedina odredba SZ-a nije suglasna s Ustavom, da zastane s postupkom i da podnese Ustavnom sudu zahtjev za ocjenu suglasnosti tog zakona, odnosno pojedine njegove odredbe s Ustavom, tzv. exceptio illegalitatis (čl. 37. UZUS) iako pravno bitna, za poslovanje subjekta predstavlja otežavajući čimbenik jer činjenica pokretanja stečajnog postupka ima negativne poslovne posljedice, primjerice, otežano sudjelovanje u postupcima javne nabave (vidi čl. 254., st. 1., t. 2. Zakona o javnoj nabavi, NN, 120/16). Također, bitno je istaknuti kako bi Ustavni sud trebao donijeti konačnu odluku, temeljem čl. 33. UZUS-a, u roku od jedne godine. Ipak budući da postupanje Ustavnog suda izvan navedenog roka nije ni do sada bilo vezano ni uz kakve posljedice o odlučivanju, prema stajalištu vladajuće 


\section{POREDBENO-PRAVNI OSVRT}

Prijedlog vjerovnika za otvaranje stečajnog postupka možemo analizirati s njegova materijalnog i procesno-pravnog aspekta. Pod materijalno-pravnim aspektom doktrina podrazumijeva, prije svega, uvjete koje vjerovnik mora ispuniti kako bi njegov prijedlog bio uredan. Oni se tiču: a) broja vjerovnika; b) samog potraživanja (minimalan iznos potraživanja, radi li se o neosiguranom potraživanju, o neuvjetovanom potraživanju, o dospjelom potraživanju, o određenom potraživanju, o neosporenom potraživanju) te c) koji su dokazi da je ispunjen uvjet za otvaranje stečaja (stečajni razlog). Kada govorimo o procesno-pravnom aspektu, svaki prijedlog koji se podnosi sudu u pisanoj formi mora imati odgovarajuću formu i sadržaj. ${ }^{12}$ Ipak pitanje pokretanja stečajnog postupka od strane vjerovnika nije jedinstveno uređeno u praksi, tj. kriteriji kojima se utvrđuje postojanje vjerovnikove tražbine kao i postojanje stečajnog razloga se razlikuju među zakonodavstvima. ${ }^{13}$ Štoviše, niti OECD, ${ }^{14}$ Međunarodni monetarni fond (MMF), ${ }^{15}$ Svjetska banka, ${ }^{16}$ UNCITRAL (United Nations Commission on International Trade Law), ${ }^{17}$ ALI (American Law Institute) ili UNIDROIT (International Institute for the Unification of Private Law) ${ }^{18}$ koji se bave i stečajnom regulativom, nemaju jasno stajalište koji je model najprimjereniji za praktičnu primjenu. Stoga suočene s istim problemima u području funkcionalizacije stečajno-pravne zaštite te sličnim pravno-političkim zahtjevima, države su krenule različitim putem pri reformi materijalnih i procesno-pravnih pretpostavki koje vjerovnik mora ispuniti kako bi njegov prijedlog bio dopušten. ${ }^{19}$

Zakon o stečaju Republike Srbije određuje kako vjerovnik podnosi prijedlog za

doktrine, radi se o instruktivnom roku. Vidi Crnić, J., Komentar Ustavnoga zakona o Ustavnom sudu Republike Hrvatske, Narodne novine, Zagreb, 2002., str. 77-78. Također, pri podnošenju takvog zahtjeva treba imati na umu stajalište Ustavnog suda koje naznačuje da aktivitet suda, kada se obraća Ustavnom sudu u postupku ocjene ustavnosti pravnih normi, jest aktivitet tijela državne vlasti (institucionalni kriterij) koje pred Ustavnim sudom mora predstavljati predsjednik suda kao najviše tijelo sudske uprave u sudu, a sam zahtjev mora sadržavati i njegov potpis i pečat suda (odluka Ustavnog suda, br. U-I-4175/2013-PP od 27. kolovoza 2013., NN, 108/13.).

12 Radović, V., Prijedlog vjerovnika za pokretanje stečaja (nevoljni stečaj), Pravo i privreda, 2002., br. 9-12, str. 161-174.

13 Id., Stečajni razlog, Pravo i privreda, 2003., br. 5-8, str. 1028-1042.

14 Vidi, OECD, Creditor Rights in Insolvency Procedure, Sydney, 1999.

15 Vidi, IMF, Orderly and Effective Insolvency Procedures, Washington, DC, 1999.

16 Vidi, World Bank, Principles and Guidelines for Effective Insolvency and Creditor Rights Systems, Washington, 2001.

17 Vidi, UNCITRAL, Legislative Guide on Insolvency Law, 2004.

18 Vidi, AMERICAN LAW INSTITUTE (ALI), Transnational Insolvency Project, Principal of Cooperation in International Insolvency Cases among members of the North America Free Trade Agreement, Report to ALI, 2012.

19 S obzirom na to da stečajni zakoni svih zemalja omogućavaju vjerovnicima podnošenje prijedloga za pokretanje stečajnog postupka, jasno je da to pravo može biti zlouporabljeno. Kada su uvjeti koje vjerovnik treba ispuniti manji, to je veća mogućnost zloupotreba. Iz tog razloga usporedna zakonodavstva predviđaju čitav niz zaštitnih odredaba, čiji je cilj da sa jedne strane, zaštite dužnika, a sa druge strane, da kazne nesavjesnog vjerovnika. Tako i detaljnije, Radović, V., op. cit., str. 170. et seq. 
pokretanje stečajnog postupka u slučaju postojanja trajnije nesposobnosti plaćanja, ne postupanja po usvojenom planu reorganizacije i ako je plan reorganizacije isposlovan na prijevaran ili nezakonit način. ${ }^{20} \mathrm{U}$ njihovoj sudskoj praksi postavilo se pitanje može li stečajni vjerovnik čije je potraživanje sporno biti ovlašteni podnositelj prijedloga za otvaranje stečajnog postupka. To je bitno pitanje jer po podnošenju prijedloga i utvrđivanju postojanja stečajnog razloga, kada je stečajni postupak otvoren odlukom suda, daljnji postupak sprovodi sud ex offo. Stoga, više nema mogućnosti da se isti obustavi i ako se nakon toga pokaže da je potraživanje vjerovnika koji je podnio prijedlog za otvaranje stečajnog postupka neosnovano. Nerješavanje ovog pitanja dovodilo je do raznih zloupotreba. Sudska praksa zauzela je stajalište da samo vjerovnici čija su potraživanja nesporna ili vjerovnici čija su potraživanja sporna, ali se učine vjerojatnim (podnošenjem dokumentacije uz prijedlog) i tu vjerojatnoću prihvati stečajni sudac, mogu podnijeti prijedlog za otvaranje stečajnog postupka. ${ }^{21}$

Zakon o stečajnom postupku Federacije Bosne i Hercegovine određuje kako vjerovnik može pokrenuti stečajni postupak, a pritom je vjerovnik dužan u prijedlogu prilaganjem odgovarajuće dokumentacije učiniti vjerojatnim svoje potraživanje i platežnu nesposobnost stečajnog dužnika. ${ }^{22}$ Kako se navedeno rješenje u praksi pokazalo spornim u prijedlogu novog Stečajnog zakona Federacije Bosne i Hercegovine iz 2016. ${ }^{23}$ našlo se rješenje identično hrvatskom? Naime, čl. 58., st. 3. Prijedloga Stečajnog zakona određuje kako je "Povjerilac dužan u prijedlogu za otvaranje stečajnog postupka, prilaganjem odgovarajuće dokumentacije, učiniti vjerojatnim svoje potraživanje i platežnu nesposobnost stečajnog dužnika. Smatrat će se da je povjerilac učinio vjerojatnim postojanje svoga potraživanja ako njegovo postojanje temelji na izvršnoj ispravi ili na nepravomoćnoj sudskoj ili upravnoj odluci." Ovo pokazuje kako prijedlozi zakona, koji se ne temelje na homogenom, u praksi ispitanom osnovnom sustavu, ipak su najčešće i zakoni s kojima se ni u drugim pravnim sustavima nema iskustva. Naime, takva su iskustva posebice bitna za BiH koja je pod vremenskim i političkim pritiskom implementirati i revidirati niz zakona jer su u tijeku sveobuhvatne reforma propisa uvjetovane ponajprije postupkom usklađivanja s propisima EU-a. ${ }^{24}$

Ipak pitanje nespornosti potraživanja, po shvaćanju doktrine, najdetaljnije je razrađeno u engleskom pravu. Ono se odnosi na institut statutory demand, kao jedan od osnovnih uvjeta koje vjerovnik koji pokreće stečajni postupak, a nema ovršnu ispravu mora ispuniti. Načelno, radi se o zahtjevu kojim se traži od dužnika da dospjelo potraživanje isplati ili osigura odnosno da za nedospjelo potraživanje učini vjerojatnim mogućnost isplate o dospjelosti. Ako protekne određeno kraće razdoblje (zakonski rok) od podnošenja zahtjeva, a dužnik ne isplati, ne osigura

20 Sl. glasnik Republike Srbije, 104/09., 99/11., 71/12. i 83/14., čl. 55.

21 Podrobnije, Ajnšpiler Popović, G., Poverioci kao podnosioci predloga za pokretanje stečajnog postupka, Pravo i privreda, 2011., br. 4-6, str. 303-314.

22 Sl. novine Federacije Bosne i Hercegovine, 29/03, 33/04, 47/06., čl. 4., st. 1.

23 Vidi Prijedlog zakona o stečajnom postupku na mrežnim stranicama: http://www.upfbih.ba/ attachments /article/556/ Zakon \%20o\%20ste\%C4\%8Daju.pdf (27.12.2016.).

24 Sporazum o stabilizaciji i pridruživanju, čl. 70. i 78. Dostupno na mrežnim stranicama: http:// www. dei.gov.ba/bihieu/ssp/default.asp x?id=1172\&langTag=bs-BA (12.01.2017.). 
ili ne učini vjerojatnim isplatu, vjerovnik može podnijeti prijedlog za pokretanje stečajnog postupka. Naravno, on mora dokazati i postojanje stečajnog razloga, što nije problematično, a kao opći i najčešći razlog za pokretanje stečajnog postupka uzima se dužnikova trajnija nesposobnost za plaćanje koja se odražava u njegovoj obustavi plaćanja dospjelih tražbina. S druge strane, dužnik koji inicira spor protiveći se takovom zahtjevu podnosi application to set aside statutory demand, a pritom postoje četiri osnove na kojima dužnik može temeljiti svoj prigovor. ${ }^{25}$

Zanemarujući problematiku definiranja stečajnog razloga, kratka poredbeno pravna analiza kao i doktrina ukazuju kako vjerovnici dužnika koji žele pokrenuti stečajni postupak moraju imati potraživanje koje je određeno i nesporno. ${ }^{26}$

\section{OSVRT NA PRAKSU ESLJP-A O PODNOŠENJU I IZVOĐENJU DOKAZA U KONTEKSTU PRAVA NA POŠTENO SUĐENJE}

U praksi i u doktrini stvoren je dojam da su hrvatske reforme insolvencijskog prava stvorile pravnu konfuziju, pa i po pitanju pravne kvalitete prijedloga za pokretanje stečajnog postupka koji je podnio vjerovnik. Čini se da je ključ prevladavanja nekih ustaljenih stajališta u analizi jurisprudencije ESLJP-a, pogotovo jer je ESLJP svojom praksom utvrdio kako i stečajni postupci potpadaju pod građanske predmete. ${ }^{27} \mathrm{U}$ tom smislu, činjenica je da se u postupku stečaja, u pravilu, ne "utvrđuju prava i obveze građanskopravne prirode", već se ona prinudno izvršavaju. ${ }^{28}$ To bi trebala biti ideja vodilja pri formiranju preduvjeta za pokretanje stečajnog postupka koji je pokrenuo vjerovnik. To ne znači da je postupak stečaja tehničkog karaktera, jer je stečajni postupak bez sumnje "upad" u imovinskopravnu sferu dužnika i vjerovnika, što zahtijeva visok stupanj pravne sigurnosti i transparentnosti. Stoga, sasvim je legitimno, a s praktičnog aspekta uglavnom opravdano i korisno analizirati praksu

25 Čl. 268. Insolvency Act c. 45. Tako Radović, V., op. cit., str. 168. et seq.

26 Za podrobnije bi trebalo pogledati izvješće o pokretanju insolvencijskih postupaka za 20 zemalja, Faber, D., Vermunt, N., Kilborn, J., Richter, T. (eds.), Commencement of Insolvency Proceedings, Oxford - International and Comparative Insolvency Law series, Oxford, 2012., str. 1-952.

27 Naime, u odluci u predmetu Ismeta Bačić protiv Hrvatske, presuda, 19. lipnja 2008., br. 43595/06. istaknuo je kako je primjenjivost čl. 6. na stečajni postupak neupitna, (S.p.r.l. ANCA i ostali protiv Belgije, odluka, 10. prosinca 1984., br. 10259/83, Interfina and Christian della Faille d'Huysse protiv Belgije, odluka, 4. svibnja 1987., br. 11101/84, Bassani protiv Italije, presuda, 11. prosinca 2003., br. 47778/99, Capital Bank AD protiv Bugarske, presuda, 24. studeni 2005., br. 49429/99 i Sukobljević protiv Hrvatske, presuda, 2. studeni 2006., br. 5129/03.) pa je i u stečajnim postupcima potrebno voditi računa o pravu na pošteno suđenje prema čl. 6. EKLJP-a kao i relevantnoj praksi ESLJP.

28 Stečajni postupak je po svojoj pravnoj prirodi izvanparnični postupak, pa u okviru takvog postupka nije moguće dokazivanje niti raspravljanje o spornim činjenicama. Sve ono što stečajni vjerovnik tvrdi u žalbi na rješenje kojim je upućen u parnicu, može dokazivati u parnici na koju je upućen. Stečajnom vjerovniku time nije uskraćena pravna zaštita. Radi se samo o tomu da je zakonom propisana druga metoda pravne zaštite, tj. on može dokazivati postojanje osporene tražbine u parnici na koju je upućen i koju je dužan pokrenuti u zakonom propisanom prekluzivnom roku. Predmet: St-257/13 od 21. lipnja 2013. potvrđeno rješenjem Pž-7146/13 od 24. rujna 2013. 
ESLJP-a u pitanjima dokazivanja. Namjera je da se analizom dugogodišnje prakse dođe do saznanja o pravno-logičkom mehanizmu odlučivanja ESLJP-a te uvidi predstavlja li dokazivanje vjerojatnosti tražbine na temelju nepravomoćne sudske i upravne odluke povredu načela jednakosti sredstava. ${ }^{29}$

Pravo na pošteno suđenje prema čl. 6. ne propisuje pravila o podnošenju, izvođenju i procjenjivanju dokaza pred nacionalnim sudovima u građanskim postupcima. Svaka država za sebe treba donijeti takve propise. ${ }^{30}$ Također, ni ESLJP nije u svojoj sudskoj praksi postavio nova načela koja bi u dokaznom postupku morale poštovati države članice EKLJP-a. Ovdje je uzeo u obzir velike razlike u nacionalnim pravnim sustavima u pogledu podnošenja i izvođenja dokaza te posebice činjenicu da common law sustavi strogo propisuju ta pravila, a civil law sustavi imaju vrlo malo ograničenja u tom području. Međutim, ESLJP je ovdje postavio određene kriterije kojima ispituje navedena pravila utvrđena u nacionalnim sustavima država članica. ${ }^{31}$ U predmetu Schenk protiv Švicarske ${ }^{32}$ u pogledu nezakonito pribavljenih dokaza, ESLJP opisao je svoj pristup određivanja poštenog suđenja gdje naglašava da njegova ocjena predstavlja dio cjelokupnog pristupa: "Iako čl. 6. EKLJP sadrži pravo na pošteno suđenje, on ne propisuje nikakva pravila o prihvaćanju dokaza kao takvih, iz čega slijedi da je to materija koju prvenstveno reguliraju države svojim zakonima. Uloga ESLJP-a nije da odluči ... primjerice, mogu li se podnijeti određeni dokazi... ESLJP odlučuje je li cjelokupan postupak, uključujući i provođenje dokaznog postupka, gledan u cijelosti bio pošten." U predmetu Elsholz protiv Njemačke ${ }^{33}$ potvrdio je to svoje stajalište navodeći: "zadatak ESLJP-a prema EKLJP je utvrditi je li cjelokupan postupak bio pošten, uključujući i izvođenje dokaza." U Blücher protiv Češke $e^{34}$ je istaknuo: "... mora se utvrditi je li dokazni postupak proveden tako da jamči poštenost postupka u cijelosti prema čl. 6." Dužnost nacionalnih sudova je da osiguraju pravilno podnošenje i izvođenje dokaza koje su predložile stranke u postupku. ${ }^{35}$ Dakle, uzimajući u obzir sve okolnosti pojedinog predmeta o kojemu odlučuje, ESLJP će odlučiti je li pošteno proveden dokazni postupak, uvažavajući ravnopravnost stranaka te je li to dovelo do povrede prava na pošteno suđenje prema čl. 6. ili nije.

\section{UMJESTO ZAKLJUČKA}

Juristička matematika nalaže kako zakonodavcu nije dopušteno ponovno donijeti, kroz drugi normativni akt, identično zakonsko rješenje koje je ranije stavio izvan snage Ustavni sud, ako su relevantne činjenice i okolnosti ostale

29 Vidjeti, Omejec, J., Zabrana diskriminacije u praksi Europskog suda za ljudska prava, Zbornik Pravnog fakulteta u Zagrebu, vol. 59, 2009., no. 5, str. 873-979.

30 Vidi, Schenk protiv Švicarske, presuda, 12. srpnja 1988., br. 10862/84.

31 Harris, D. J., et al., Law of the European Convention on Human Rights, Oxford University Press, Oxford, 2014., str. 256-257.

32 Schenk protiv Švicarske, presuda, 12. srpnja 1988., br. 10862/84.

33 Elsholz protiv Njemačke, presuda, 13. srpnja 2000., br. 25735/94.

34 Blücher protiv Češke, presuda, 11. siječnja 2005., br. 58580/00.

35 Harris, D. J., et al., op. cit., str. 258. 
neizmijenjene. ${ }^{36}$ Nomotehnički pristup kojim se rješenje koje je stavljeno izvan snage ponovno implementira u novi SZ, prema stajalištu autora, ali i vladajuće doktrine, otvara niz procesnih i materijalno pravnih te, u konačnici, i ustavnopravnih pitanja. Ono na što smo se fokusirali u radu je procesno pitanje tereta dokazivanja tražbine. Naime, polazeći od činjenice da se u stečajnom postupku odgovarajuće primjenjuju pravila parničnog postupka (čl. 10. SZ), čl. 109., st. 2. SZ-a ulazi u područje dokaznog postupka i pravila o teretu dokazivanja u parničnom postupku. Kako se vjerojatnost tražbine dokazuje podnošenjem prijedloga temeljenog na nepravomoćnoj odluci, to može rezultirati "bankrotom" dužnika čak i ako se pravomoćno utvrdi kako ne postoji nikakva tražbina vjerovnika prema dužniku. ${ }^{37}$ Time se dovodi u pitanje i jednakost stranaka budući da je vjerovnik u povoljnijem položaju jer svoju tražbinu može temeljiti na nepravomoćnoj sudskoj ili upravnoj odluci. Time se dužnik stavlja u procesno lošiji položaj u odnosu na suprotnu stranku pa je i opravdano pitanje tko je odgovoran kada se nad dužnikom otvori i provede stečajni postupak, a tražbina stečajnog vjerovnika, prema postojećem načelu vjerojatnosti utvrđena nepravomoćnom presudom, kasnije pravomoćnom presudom, bude utvrđena nepostojećom? ${ }^{38}$ Prema mišljenju autora, odgovornost je na državi. Tu se može postaviti zanimljivo (političko pravno) pitanje - može li se postupovna neravnopravnost stranaka u stečajnom postupku opravdati političkom potrebom za funkcionalizacijom stečajnog postupka. U predmetu Guincho protiv Portugala ${ }^{39}$ gdje je podnositelj pokrenuo postupak pred ESLJP-a zbog povrede čl. 6., st. 1. tužena država je istaknula kako su u to vrijeme u Portugalu bile izvanredne okolnosti. ESLJP je to prihvatio i utvrdio da "privremena preopterećenost sudova ne predstavlja, odmah, međunarodnu odgovornost države prema EKLJP, ako država odmah poduzme učinkovite mjere za uklanjanje takve situacije." Iako je poduzeto nekoliko mjera kako bi pravosudni sustav bio učinkovit i kako bi postupci bili pravični, ESLJP je zaključio kako su one bile nedovoljne i provedene sa zakašnjenjem te je utvrdio povredu čl. 6. U odnosu na problematiku rada norma i judikatura pokazuju da u pravnom poretku Republike Hrvatske ne postoje pravni mehanizmi kojima bi se Hrvatski sabor ili Vlada Republike Hrvatske prisilili na izvršenje odluka Ustavnog suda kojima se ukidaju zakoni ili drugi propisi, odnosno pojedine njihove odredbe, zbog nesuglasnosti s Ustavom. ${ }^{40}$ Dakle, ostaje dojam kako se usvojenim propisima u domeni stečajnog zakonodavstva formalno ne mogu uputiti bitnije primjedbe, već je odsustvo kolektivne strategije vjerojatno uzrok da oko reforme nije bilo moguće okupiti djelotvorne reformske snage.

36 Ustavno sudstvo (odgovori na postavljena pitanja) - Funkcioniranje i odnos sa drugim tijelima javne vlasti i odgovori Ustavnog suda Republike Hrvatske, dostupno na mrežnim stranicama (12.12.2016.).

37 Tako i podrobnije Šernhorst, N., Postojanje tražbine kao uvjet dopuštenosti prijedloga za otvaranje stečajnog postupka, Pravo i porezi, 2015., br. 4, str. 31-33., id., Pravna nesigurnost u primjeni novog Stečajnog zakona, Informator, 2016., br. 6401, str. 20-21. Više o dokazivanju, Triva, S., Dika, M., Građansko parnično procesno pravo, Narodne novine, Zagreb, 2004., str. 480-532.

38 Šernhorst, N., Postojanje tražbine kao uvjet dopuštenosti... cit., str. 31-33.

39 Guincho protiv Portugala, presuda, 10. srpnja 1984., Serija A., br. 81.

40 Ustavno sudstvo (odgovori na postavljena pitanja), op. cit. 
U konačnici, smatramo da je hrvatski zakonodavac pogriješio kada je implementirao čl. 13., st. 1. ZID-a starog Stečajnog zakona (NN, 133/12.) te kada je postupio istovjetno s odredbom čl. 109., st. 2. SZ-a (NN, 71/15.). U oba puta nepotrebno je intervenirao u odredbu "vjerovnik je ovlašten podnijeti prijedlog za otvaranje stečajnog postupka ako učini vjerojatnim postojanje svoje tražbine i kojega od stečajnih razloga". Dio te odredbe "vjerojatnost postojanja tražbine" predstavlja pravni standard, čiji su opseg i značenje trgovački sudovi tijekom svoje višegodišnje prakse sami stvorili i tumačili te što u konačnici nije bilo sporno. Legitimaciju za pokretanje stečajnog postupka vjerovnik nije morao dokazati postojanjem tražbine, a niti je morao dokazati da je postojanje te tražbine utvrđeno presudom, već je bilo dostatno da učini vjerojatnim postojanje tražbine. Općenito uzevši, sucima je kod izvođenja zaključaka u tom pravcu dano ovlaštenje reducirati svoja uvjerenja sa stupnja izvjesnosti na stupanj vjerojatnosti. Pritom se polazi od utvrđenja o postojanju više argumenata koji govore u prilog uvjerenja o postojanju relevantnih činjenica nego onih koji govore protiv. Međutim, pritom broj argumenta na jednoj strani sam po sebi ne mora biti odlučan, već je odlučan sadržaj, odnosno snaga tih argumenata. ${ }^{41}$ To potvrđuje i obrazloženje Odluke Ustavnog suda br. U-III-4963/2008 od 30.03.2011. u kojem se naglašava da na Ustavnom sudu "nije tumačiti mjerodavno pravo", ali se skreće i pozornost na pravo dužnika na očitovanje o relevantnim činjenicama, a kojima bi mogao otkloniti pokretanje odnosno otvaranje stečajnog postupka sukladno sa zahtjevima čl. 29., st. 1. Ustava RH.

U cjelini gledano, kada je riječ o procjeni "pravičnosti" u postupku dokazivanja u smislu čl. 6., st. 1. EKLJP-a, smatramo kako su odredbama čl. 109., st. 2. novog SZ-a (ponovno) prekršena autonomna načela "pravičnosti" u značenju čl. 6. EKLJP-a od kojih je bitno načelo "jednakosti procesnih sredstava".

\section{LITERATURA}

Ajnšpiler Popović, G., Poverioci kao podnosioci predloga za pokretanje stečajnog postupka, Pravo i privreda, 2011., br. 4-6.

AMERICAN LAW INSTITUTE (ALI), Transnational Insolvency Project, Principal of Cooperation in International Insolvency Cases among members of the North America Free Trade Agreement, Report to ALI, 2012.

Bodul, D., Vuković, A., Institucionalni okvir za primjenu stečajnog zakonodavstva - otvorena pitanja, Informator, 2017., br. 6452.

Bodul, D., Vuković, A., Pouzdanost kriterija za pokretanje stečajnog postupka, Pravni portal: IUS-INFO, 2016. Dostupno na mrežnim stranicama: http://www. iusinfo.hr/ (12.12.2016.).

Crnić, J., Komentar Ustavnoga zakona o Ustavnom sudu Republike Hrvatske, Narodne novine, Zagreb, 2002.

Dutertre, G., Izvodi iz sudske prakse - Evropski sud za ljudska prava, IMTEC, Sarajevo, 2002.

Faber, D., Vermunt, N., Kilborn, J., Richter, T. (eds.), Commencement of Insolvency Proceedings, Oxford - International and Comparative Insolvency Law series, Oxford, 2012.

41 Predmet St-1571/11 od 11. veljače 2013. potvrđeno rješenjem P̌̌-3560/13 od 05. lipnja 2013. 
Gomien, D., Europska konvencija o ljudskim pravima, Rijeka, Naklada, Pravni fakultet Sveučilišta u Rijeci, 2007.

Grbić, S., Pošteno suđenje u građanskim postupcima u Hrvatskoj u svjetlu čl. 6., st. 1. Europske konvencije o ljudskim pravima, Pravni fakultet, Rijeka, 2014.

Guide on Article 6 of the Convention - Right to a fair trial (civil limb), Council of Europe, 2013., dostupno na mrežnim stranicama: http://www.echr.coe.int/ Documents/Guide Art_6_ENG.pdf (20.11.2016.).

Harris, D. J., et al., Law of the European Convention on Human Rights, Oxford University Press, Oxford, 2014.

IMF, Orderly and Effective Insolvency Procedures, Washington, DC, 1999.

Ivičević Karas, E., Načelo jednakosti oružja kao konstitutivni element prava na pravični kazneni postupak iz članka 6. Europske konvencije za zaštitu ljudskih prava i temeljnih sloboda, Zbornik Pravnog fakulteta Sveučilišta u Zagrebu, vol. 57, 2007., br. 4 -5.

OECD, Creditor Rights in Insolvency Procedure, Sydney, 1999.

Omejec, J., Zabrana diskriminacije u praksi Europskog suda za ljudska prava, Zbornik Pravnog fakulteta u Zagrebu, vol. 59, 2009., no. 5.

Radović, V., Prijedlog vjerovnika za pokretanje stečaja (nevoljni stečaj), Pravo i privreda, 2002., br. 9-12.

Radović, V., Stečajni razlog, Pravo i privreda, 2003., br. 5-8.

Reid, K., A Practitioner's guide to European Convention on Human Rights, London, Sweet \& Maxwell, Thomson Reuters, 2012.

Smerdel, B., Znanost, struka i politika: ustavne promjene, Informator, 2009., br. 5812.

Stavros, S., The guarantees for accused persons under article 6 of the European Convention on Human Rights, An Analysis of the Application of the Convention and a comparison with Other Instruments, Martinus Nijhoff Publishers, Dordrecht, Boston, London, 1993.

Šernhorst, N., Postojanje tražbine kao uvjet dopuštenosti prijedloga za otvaranje stečajnog postupka, Pravo i porezi, 2015., br. 4.

Šernhorst, N., Pravna nesigurnost u primjeni novog Stečajnog zakona, Informator, 2016., br. 6401

Triva, S., Dika, M., Građansko parnično procesno pravo, Narodne novine, Zagreb, 2004.

UNCITRAL, Legislative Guide on Insolvency Law, 2004.

Ustavno sudstvo (odgovori na postavljena pitanja) - Funkcioniranje i odnos sa drugim tijelima javne vlasti i odgovori Ustavnog suda Republike Hrvatske, dostupno na mrežnim stranicama (12.12.2016.).

World Bank, Principles and Guidelines for Effective Insolvency and Creditor Rights Systems, Washington, 2001.

Insolvency Act c. 45.

Konvencija za zaštitu ljudskih prava i temeljnih sloboda, NN - MU, 18/97., 6/99., 14/02., 13/03., 9/05., 1/06. i 2/10.

Prijedlog Stečajnog zakona na mrežnim stranicama http://www.upfbih.ba/attachments/ article/556/ Zakon \%20o\%20ste\%C4\%8Daju.pdf. (27.12.2016.).

Stečajni zakon, NN, 44/96., 29/99., 129/00., 123/03., 82/06., 116/10., 25/12. i 45/13.

Stečajni zakon, NN, 71/15.

Uredba o kriterijima i načinu obračuna i plaćanja nagrade stečajnim upraviteljima, NN, $105 / 15$.

Uredba o uvjetima, načinu i postupku raspolaganja tražbinama s naslova poreznog duga u predstečajnom i stečajnom postupku, NN, 122/15.

Ustav RH, NN, 56/90., 135/97., 8/98., 113/00., 124/00., 28/01., 41/01., 55/01., 76/10., 85/10., $05 / 14$.

Ustavni zakon o Ustavnom sudu Republike Hrvatske, NN, 99/99., 29/02. i 49/02.

Zakon o osiguranju potraživanja radnika u slučaju stečaja poslodavca, NN, 86/08., 80/13. i $82 / 15$. 
Zakon o radu, NN, 93/14.

Zakon o stečajnom postupku Federacije Bosne i Hercegovine Sl. novine Federacije Bosne i Hercegovine, 29/03., 33/04., 47/06.

Zakon o stečaju potrošača, NN, 100/15.

Zakon o stečaju Republike Srbije, Sl. glasnik Republike Srbije, 104/09., 99/11., 71/12. i $83 / 14$.

Zakon o javnoj nabavi, NN, 120/16.

Bassani protiv Italije, presuda, 11. prosinca 2003., br. 47778/99.

Blücher protiv Češke, presuda, 11. siječnja 2005., br. 58580/00.

Bonisch protiv Austrije (presuda, 2. lipnja 1986., br. 8658/79.

Capital Bank AD protiv Bugarske, presuda, 24. studeni 2005., br. 49429/99.

De Haes i Gijsels protiv Belgije (presuda, 24. veljače 1997., br. 19983/92.

Delcourt protiv Belgije (presuda, 17. siječnja 1970., br. 2689/65.

Dombo Beheer protiv Nizozemske (presuda, 27. listopada 1993., br. 14448/88.

Elsholz protiv Njemačke, presuda,13. srpnja 2000., br. 25735/94.

F. R. protiv Švicarske presuda 28. lipnja 2001., br. 37292/97.

Feldbrugge protiv Nizozemske, presuda, 27. srpnja 1987., br. 8562/79.

Ferreira Alves protiv Portugala, presuda, 21. lipnja 2007., br. 25053/05.

Guigue i SGEN-CFDT protiv Francuske, odluka, 6. siječnja 2004., br. 59821/00.

Guincho protiv Portugala, presuda, 10. srpnja 1984., Serija A., br. 81.

Interfina and Christian della Faille d'Huysse protiv Belgije, odluka, 4. svibnja 1987., br. $11101 / 84$.

Ismeta Bačić protiv Hrvatske, presuda, 19. lipnja 2008., br. 43595/06.

LB INTERFINANZ A.G. protiv Hrvatske, presuda, 27.03.2008., zahtjev br. 29549/04.

McMichael protiv Ujedinjenog Kraljevstva, presuda, 24. veljače 1995., br. 16424/90.

Neumeister protiv Austrije (presuda, 27. lipnja 1968., br. 1936/63.

S.p.r.l. ANCA i ostali protiv Belgije, odluka, 10. prosinca 1984., br. 10259/83.

Schenk protiv Švicarske, presuda, 12. srpnja 1988., br. 10862/84.

Stran Greek Refineries i Stratis Andreadis protiv Grčke, presuda, 9. prosinca 1994., br. $13427 / 87$.

Sukobljević protiv Hrvatske, presuda, 2. studeni 2006., br. 5129/03.

Szwabowic protiv Švedske, odluka, 30. lipnja 1959., br. 434/58.

Odluka Visokog trgovačkog suda RH, br. Pž-4746/08 od 30.09.2008.

Odluka Visokog trgovačkog suda RH, br. Pž-4331/09-3 od 30.07.2009.

Odluke Ustavnog suda RH, br. U-III-4963/2008. od 30.03.2011.

Odluka Trgovačkog suda, St-1571/11 od 11.02.2013. potvrđeno rješenjem Pž-3560/13 od 05.06.2013.

Odluka Trgovačkog suda, br. St-67/13 od 28.02.2013

Rješenje Ustavnog suda RH, U-I/1457/2013. od 11.04.2013., NN, 45/13.

Odluka Trgovačkog suda, St-257/13 od 21.06.2013. potvrđeno rješenjem Pž-7146/13 od 24.09.2013.

Odluka Ustavnog suda, br. U-I-4175/2013-PP od 27.08.2013., NN, 108/13. 
Summary

\section{CONTRIBUTION TO THE DEBATE ON THE PRINCIPLE OF EQUALITY OF ARMS}

The principle of equality of arms requires that each party to the proceedings should have equal opportunity to present facts and support them with their evidence without of putting any party in a substantial disadvantage. (Case LB INTERFINANZ AG against Croatian, judgment, 27.03.2008 ., application no. 29549/04.). In terms of the procedural balance between the parties, this principle constitutes one of the essential elements of the right to a fair trial. However, the question of equality of arms is again raised in Bankruptcy Act (Official Gazette, 71/15. hereinafter: BA). BA has kept solution in which the creditor is able to initiate bankruptcy proceedings if he makes the existence of its claims likely possible and the existence of the reasons for bankruptcy. However, the legislator has retained the disputed solution in which the probability of the existence of the creditor claim can be proven by non-final judicial or non-final administrative decisions.

As there are different solutions in terms of the above mentioned assumptions, the authors will focus on general statements based on comparative experiences, without detail consideration of the numerous and specific comparative solutions. This paper discusses the practical, but also theoretical implications of positive legal solutions specifically analysing the law of the European Court of Human Rights (ECtHR) in proceedings according to Art. 6 (right to a fair trial) of the European Convention for the Protection of Human Rights and Fundamental Freedoms (ECHR), because we assume that these information play key role in the understanding of the issue concerned. In addition, authors are trying to get the answer on the question will overall unsatisfied indicators of bankruptcy proceedings, which are the result of structural problems, need "stringent" procedural measures to resolve that situation. The subject of the paper is also a nomotehnical dimension of this issue, because the same solution was in the old Bankruptcy Act (Official Gazette, 44/96, 29/99, 129/00, 123/03, 82/06, 116/10, 25/12, and 45/13.) which suspended the Constitutional Court.

Keywords: bankruptcy, the institution of proceedings, creditor, the likelihood of a claim, proof.

Zusammenfassung

\section{BEITRAG ZUR DEBATTE ÜBER DEN GRUNDSATZ DER VERFAHRENSMITTEL}

Der Grundsatz der Verfahrensmittel sieht vor, dass jeder Verfahrensbeteiligte die Möglichkeit hat, Tatsachen vorzulegen und sie mit ihren Beweismitteln zu unterstützen, 
ohne dass eine Partei einen erheblichen Nachteil erleidet. (Rechtsverfahren LB INTERFINANZ AG gegen Kroatien, Urteil vom 27 März 2008, Antrag Nr. 29549/04). In Bezug auf das prozessuale Gleichgewicht zwischen den Parteien ist dieses Prinzip eines der wesentlichen Elemente des Rechts auf ein faires Verfahren. Jedoch wird die Frage der Gleichheit der Verfahrensmittel wieder im Konkursgesetz (Amtsblatt, 71/15, nachfolgend: KG) erhoben. KG hält sich an der Urteil, dass der Gläubiger in der Lage ist, ein Insolvenzverfahren einzuleiten, wenn er die Existenz seiner Ansprüche die Existenz der Gründe für den Konkurs wahrscheinlich machen kann. Der Gesetzgeber hat jedoch die streitige Lösung beibehalten, in der die Wahrscheinlichkeit des Vorliegens des Gläubigeranspruchs durch nicht endgültige gerichtliche oder nicht abschließende Verwaltungsentscheidungen nachgewiesen werden kann.

Da es im Hinblick auf die oben genannten Annahmen unterschiedliche Lösungen gibt, konzentrieren sich die Autoren auf allgemeine Aussagen, die auf vergleichenden Erfahrungen basiert sind, ohne in Detail die zahlreichen und spezifischen Vergleichslösungen zu betrachten. In diesem Beitrag werden praktische aber auch theoretische Implikationen positiver Rechtslösungen mit einem Schwerpunkt auf die Analyse der Praxis des Europäischen Gerichtshofs für Menschenrechte $(\mathrm{EuGH})$ in Verfahren nach Art. 6 (Recht auf ein faires Verfahren) der Europäischen Konvention zum Schutze der Menschenrechte und Grundfreiheiten (EMRK) diskutiert, da wir davon ausgehen, dass diese Informationen für das Verständnis der betreffenden Frage von zentraler Bedeutung sind. Darüber hinaus werden die Autoren versuchen, die Frage zu beantworten, ob die insgesamt schlechten Indikatoren des Insolvenzverfahrens, die das Ergebnis der strukturellen Probleme sind, "strenge" Verfahrensmaßnahmen fordern, um diese Situation zu lösen. Der Gegenstand des Artikels ist auch die nomographische Dimension dieser Frage, da die gleiche Lösung im alten Insolvenzgesetz (Amtsblatt, 44/96, 29/99, 129/00, 123/03, 82/06, 116/10, 25/12 und 45/13) vor dem Verfassungsgerichtshof der Republik Kroatien die Klage über die Übereinstimmung mit der Verfassung erhoben wurde und deswegen eine endgültige Ausführung einzelner Handlungen und Maßnahmen auf der Grundlage der umstrittenen gesetzlichen Bestimmungen suspendiert wurde.

Schlüsselwörter: Insolvenz, Gläubiger, Wahrscheinlichkeit eines Anspruchs, Beweis.

\author{
Riassunto
}

\title{
CONTRIBUTO AL DIBATTITO SUL PRINCIPIO DI EGUAGLIANZA DEI MEZZI PROCESSUALI
}

Il principio di eguaglianza dei mezzi processuali presuppone l'esistenza di una ragionevole possibilità in capo ad entrambe le parti di esporre e comprovare $\mathrm{i}$ fatti, in un modo che non metta alcuna delle parti in posizione sfavorevole rispetto alla controparte (caso LB INTERFINANZ A.G. v. Croazia, sentenza del 27.03.2008, 
riscorso n. 29549/04.). Un tanto rappresenta, nella sua espressione di equilibrio tra le parti processuali, uno degli elementi costitutivi del diritto ad un giusto processo. Tuttavia, con l'entrata in vigore della (nuova) legge fallimentare (GU, n. 71/15. in avanti LF) la questione dell'eguaglianza sul piano processuale diviene nuovamente di attualità. Precisamene, la LF ha mantenuto una soluzione in base alla quale il creditore ha la possibilità di instaurare il procedimento fallimentare qualora renda probabile l'esistenza del proprio credito e la sussistenza del fondamento fallimentare così che è trattenuto ed eccepito il provvedimento in base al quale la probabilità della sussistenza del credito non può venire dimostrata dal creditore sulla base di una decisione dell'autorità giudiziale o amministrativa che non sia passata in giudicato.

Posto che esistono diverse soluzioni con riguardo alle questioni illustrate, gli autori si limiteranno a delle constatazioni di carattere generale sulla base di esperienze comparate, senza una dettagliata disamina delle variegate e peculiari soluzioni giuridiche straniere. Nel lavoro si disaminano sia le implicazioni pratiche che quelle teoriche della soluzione giuridica di diritto positivo, analizzando la giurisprudenza della Corte europea dei diritti dell'uomo nei procedimenti in base all'art. 6 (diritto ad un giusto processo) della Convenzione europea per la salvaguardia dei diritti dell'uomo e delle libertà fondamentali, poiché partiamo dal presupposto che le conoscenze sul punto possono essere fondamentali per la comprensione dell'oggetto dell'indagine condotta nel lavoro. Altresì, si tenta di rispondere all'interrogativo se gli indicatori negativi del procedimento fallimentare, che derivano da problemi di carattere strutturale, non richiedano misure processualistiche più "severe" al fine di risolvere tale situazione. Sarà oggetto di analisi anche la dimensione che riguarda la tecnica normativa, visto che per la stessa soluzione nella vecchia legge fallimentare (GU, 44/96, 29/99, 129/00, 123/03, 82/06, 116/10, 25/12 e 45/13) dinnanzi alla Corte costituzionale della Repubblica di Croazia venne instaurato un procedimento per la valutazione della legittimità costituzionale e che fino alla decisione della Corte è stata provvisoriamente sospesa l'esecuzione di qualsiasi atto posto in essere in base alla disposizione di legge oggetto di ricorso.

Parole chiave: fallimento, creditore, instaurazione del procedimento, sussistenza del credito, prova. 
